\title{
Assessment of porous material anisotropy and its effect on gas permeability
}

\author{
Grzegorz Wałowski ${ }^{1, *}$ \\ ${ }^{1}$ Institute of Technology and Life Sciences, Poznan Branch, Department of Renewable Energy Sources, street Biskupińska 67, 60-463 \\ Poznań, Poland,
}

\begin{abstract}
The results of experimental research upon the assessment of porous material anisotropy and its effect on gas permeability of porous materials with respect to the gas flow. The conducted research applied to natural materials with an anisotropic gap-porous structure and - for comparative purposes - to model materials such as coke, pumice and polyamide agglomerates. The research was conducted with the use of a special test stand that enables measuring the gas permeability with respect to three flow orientations compared with symmetric cubic-shaped samples. The research results show an explicit impact of the flow direction on the permeability of materials porous, which results from their anisotropic internal structures. The anisotropy coefficient and permeability effective coefficient of such materials was determined and an experimental evaluation of the value of this coefficient was conducted with respect to the gas stream and the total pressure drop across the porous deposit. The process of gas permeability was considered in the category of hydrodynamics of gas flow through porous deposits. It is important to broaden the knowledge of gas hydrodynamics assessment in porous media so far unrecognised for the development of a new generation of clean energy sources, especially in the context of biogas or raw gas production.
\end{abstract}

\section{Introduction}

The porous medium is a natural or artificial material characterised by a vast number of channels and empty spaces with relatively dimensions in comparison with the weight of the material itself. Empty spaces, irrespective of their shape, are called pores whose form and size are affected by a kind of granular deposit. The porous structure is characteristic for both natural and artificial materials, including soil, pumice (volcanic soil), ceramic construction materials, metal agglomerates and the socalled metal foams. Porous media are divided into two fundamental groups, viz.:

a) porous media constituting loose deposits comprising granular materials that take the space resulting from the geometrically-shaped volume - Fig. 1a;

b) frame-based media that are a solid and stiff porous structure in the form of the homogeneous material deposit - Fig. 1b.

In both cases, in a particular porous medium there usually occur pores with diversified and irregular shapes that most frequently create the gap-porous space as illustrated in Fig. 1b. For circular-shaped pores (channels) or similar ones the characteristic dimension of pores is the diameter, whereas for gap-shaped channels this is width. At the same time, the size of pores and flow gaps determines the structure of porous materials.

Pursuant to the guidelines of the International Union of Pure and Applied Chemistry (IUPAC) [3] there is applied the classification of gap-porous spaces set forth in Table 1. a)

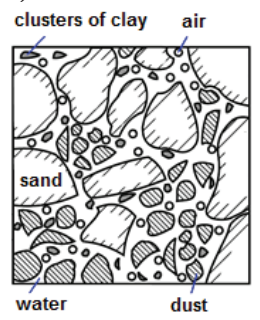

b)

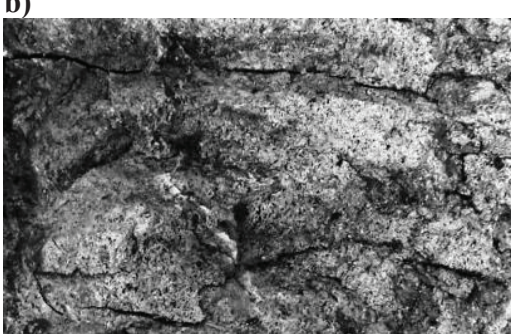

Fig. 1. Porous media are divided into two fundamental groups: a) scheme of natural soil structure [1], b) gap-porous structure of coal char [2].

As for the permeability of liquids porous media may be considered in two ways [4], viz.:

a) isotropic, if deposit filtration features have identical features in all directions of the flow;

b) anisotropic, if deposit filtration features are diversified compared to the selected direction of the flow.

The first instance proves the homogeneous structure of the porous deposit, whereas in the latter one in a specific volume there occurs a diversified directional structure of pores and flow channels. The example of isotropic and anisotropic structures is shown in Fig. 2. The fundamental characteristic of each porous material is its porosity as the dimension of part of deposit volume occupied by pores, i.e. free space $[5,6]$. 
Table 1. Classification of pores and gaps as per [3].

\begin{tabular}{|l|c|l|c|}
\hline \multicolumn{2}{|c|}{ Pores } & \multicolumn{2}{c|}{ Gaps } \\
\hline \multicolumn{2}{|c|}{$\begin{array}{c}\text { effective diameter } \\
\mathrm{d}_{\mathrm{ef}}, \mathrm{mm}\end{array}$} & \multicolumn{2}{c|}{$\begin{array}{c}\text { width } \\
\mathrm{s}, \mathrm{mm}\end{array}$} \\
\hline $\begin{array}{l}\text { micro- } \\
\text { pores }\end{array}$ & $d_{\text {ef }} \leq 210^{-3}$ & $\begin{array}{l}\text { sub- } \\
\text { capillar }\end{array}$ & $s<110^{-3}$ \\
\hline $\begin{array}{l}\text { meso- } \\
\text { pores }\end{array}$ & $210^{-3}<d_{e f} \leq 0.5$ & capillar & $0.25<s<110^{-3}$ \\
\hline $\begin{array}{l}\text { macro- } \\
\text { pores }\end{array}$ & $d_{e f}>0.5$ & $\begin{array}{l}\text { over- } \\
\text { capillar }\end{array}$ & $s>0.25$ \\
\hline \multicolumn{2}{|l|}{$*$ pore dimension in the effective flow cross-section } \\
\hline
\end{tabular}

a)
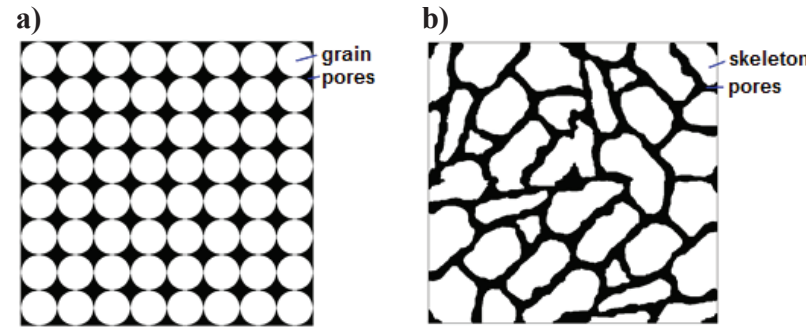

Fig. 2. Porous structure: (a) isotropic, (b) anisotropic (black: free space; white: frame-based structure).

Definition of porosity (1) is:

$$
\varepsilon=\frac{V_{o}}{V}
$$

where: $\varepsilon$ - porosity, $\mathrm{V}_{\mathrm{o}}$ - apparent volume (value calculated for the full section of the bed), $\mathrm{m}^{3} ; \mathrm{V}-$ volume, $\mathrm{m}^{3}$;

The porosity is not generally affected by dimensions of particles of the porous material but it is considerably subject to the shape of grains (pores) of this material. The example is shown in Fig. 3 - for the isotropic deposit comprising circular elements of the identical size, the porosity changes from the maximum value (2):

$$
\varepsilon_{\max }=\frac{V_{o}}{V}=\frac{\left(d_{p}^{3}-\frac{\pi d_{p}^{3}}{6}\right)}{d_{p}^{3}}=0,4764
$$

where: $\varepsilon_{\max }-$ maximum porosity; $\mathrm{V}_{\mathrm{o}}$ - apparent volume (value calculated for the full section of the bed), $\mathrm{m}^{3} ; \mathrm{V}-$ volume, $\mathrm{m}^{3}, \mathrm{dp}$ - diameter of the spherical particle, $\mathrm{m}$; for the regular cubic arrangement (Fig. 3a), up to the value of $\varepsilon=0.2595$ - for the rhombohedral structure "sphere on three spheres". Obviously, for real structures (natural materials) their porosity may exceed the maximum value and fall below the minimum value and the more the deposit structure differs from the isotropic one the greater the deviation is.

In can be assumed that the volume of free spaces directly proves the quantity (volume) of liquid to be stored in a particular deposit.

On the other hand, the pore arrangement structure and the shape of channels and of free space affect the deposit permeability. a)

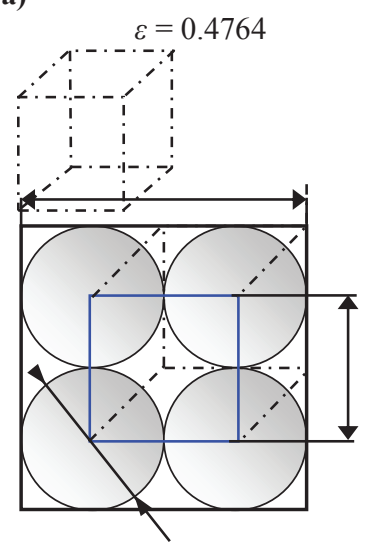

b) $\varepsilon=0.3954$

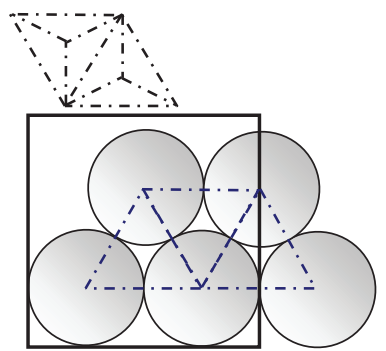

Fig. 3. Examples of isotropic structures of the porous materials: a) cubic, b) rhomboidal, c) rhombohedral [7].

In each case, this permeability which is the liquid stream going through the layer of the porous deposit is affected by the influence of pressure forces $[6,8,9]$. Of huge significance is whether the liquid flows because it is under the influence of gravitational forces or it is additionally forced by external forces due to the generated pressure.

\section{Materials and method}

The permeability research was conducted upon a number of diversified types of materials, the average porosity of which ranged from $22 \%$ to $56 \%$. Most of them were coal chars (cokes) from the thermal processing of hard coal and there are also materials like partially melted waste rocks (including volcanic ones), natural and synthetic pumice and porous agglomerate. The research material comprised various types of solid frame structures thoroughly analysed in the study by Wałowski and Filipczak [10].

To obtain the research objective, the detailed experimental tests were conducted to assess of porous material anisotropy and its effect on gas permeability of porous materials with the diversified structure and the diversified process characteristics [2]. 
The research was conducted on a specially-designed stand [11], the fundamental component of which is the flow channel inside which the porous material sample is inserted, Fig. 4a. a)

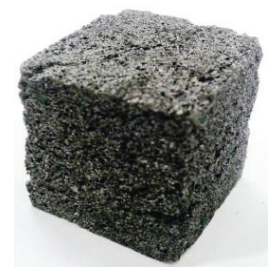

b)

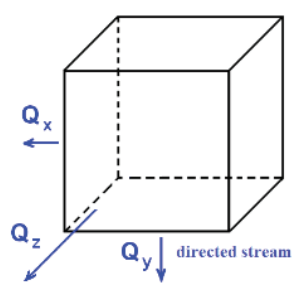

Fig. 4. Sample of research material [10]: a) $20 \times 20 \times 20 \mathrm{~mm}$ porous material, b) diagram of the gas flow through the sample.

The tested samples were cubic and the structure of the flow channel enabled measuring the gas permeability for each of the main flow directions (X, Y, Z) (Fig. 4b) through rotating the cubic sample in the selected plane of the measuring cell [10]. The gas permeability research was conducted by using air as a working medium.

The permeability measure was assumed to be a gas volume flow resulting from the allowable differential pressure forcing the gas flow on a given axis on the porous material sample.

\section{Results and discussion}

The significant feature of the porous deposit that directly results from its structure is anisotropy of the porous material and its influence on its permeability. As for its definition this feature is identified with the socalled coefficient of anisotropy [12,13,14], which is described as the root of the quotient of the permeability coefficient determined with respect to the mutually perpendicular flow planes (3):

$$
\beta=\sqrt{\frac{K_{h}}{K_{v}}}
$$

where: $\beta$ - anisotropy coefficient; $K_{h}$ - coefficient of horizontal permeability, $\mathrm{m}^{2} ; \mathrm{K}_{\mathrm{v}}$ - coefficient of vertical permeability, $\mathrm{m}^{2}$;

In specific hydrodynamic conditions this coefficient deviates from the gas flow uniformity that results from a particular flow direction - an increase in the value of this coefficient leads to a decrease in deviation from the anisotropic structure of the porous deposit.

For the horizontal plane (Fig. 5) the permeability coefficient $\mathrm{K}_{\mathrm{h}}(4)$ :

$$
K_{h}=\sqrt{K_{X} K_{Z}}
$$

where: $\mathrm{K}_{\mathrm{h}}$ - coefficient of horizontal permeability, $\mathrm{m}^{2}$; $\mathrm{K}_{\mathrm{X}}$ - coefficient of permeability in the $\mathrm{X}$ direction, $\mathrm{m}^{2}$; $\mathrm{K}_{\mathrm{Z}}$ - coefficient of permeability in the $\mathrm{Z}$ direction, $\mathrm{m}^{2}$; is most frequently determined as the geometrical average from the value of the permeability coefficient in two horizontal directions, i.e. $\mathrm{K}_{\mathrm{X}}$ and $\mathrm{K}_{\mathrm{Z}}$.
On the other hand, the permeability coefficient for the vertical plane $\mathrm{K}_{\mathrm{V}}(5)$ :

$$
\mathrm{K}_{\mathrm{v}}=\mathrm{K}_{\mathrm{Y}}
$$

where: $\mathrm{K}_{\mathrm{v}}$ - coefficient of vertical permeability, $\mathrm{m}^{2} ; \mathrm{K}_{\mathrm{Y}}$ coefficient of permeability in the Y direction, $\mathrm{m}^{2}$;

is the value resulting from the flow of gas towards the $\mathrm{Z}$ axis

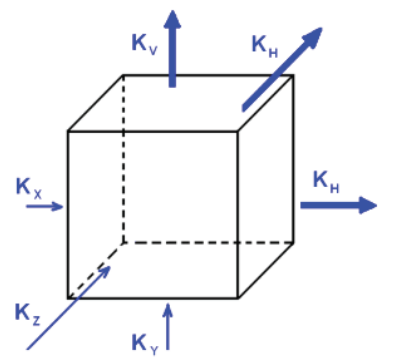

Fig. 5. Marking of flow directions and their referring calculation planes of permeability coefficient - horizontal $K_{h}$ and vertical $\mathrm{K}_{\mathrm{v}}$.

The anisotropic structure characteristic for the porous material together with the graphical model of heterogeneity of free spaces are shown in Fig. 6., and illustrated by coal char in situ. Although this image may indirectly be used to evaluate the effective porosity but it is not sufficient to describe anisotropy on a quantitative basis as it only relates to the top layer of the material, whereas the real measurement of anisotropy is the potential permeability of the deposit.

a)

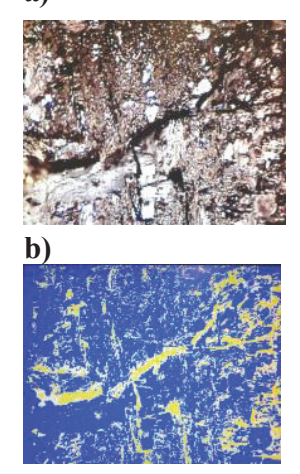

$\mathrm{X}$ direction
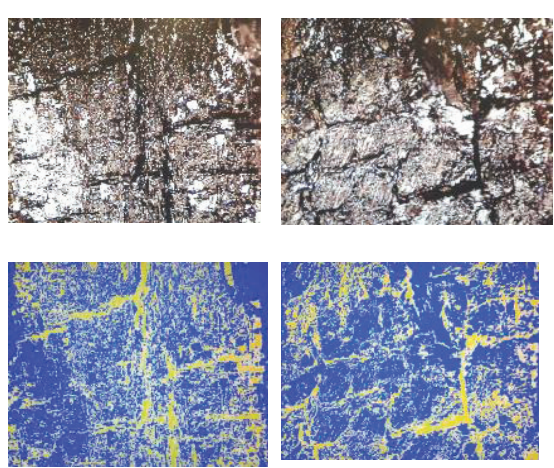

Y direction

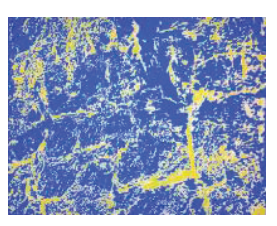

$\mathrm{Z}$ direction
Fig. 6. Image of surface of coal char in situ with diversified spatial structure.

Therefore, it is necessary to determine directional permeability coefficients as shown in Fig. 7. In each case, however, anisotropy is considerably affected by structural features of the porous material.

The research results characterising the coefficient of anisotropy for various porous materials with respect to their permeability are shown in Fig. 8. This figure is a kind of map that identifies the material structure with respect to its permeability.

It may be noticed that for the porous polyamide agglomerate, anisotropy does not practically occur (6):

$$
\beta=1
$$

where: $\beta$-anisotropy coefficient. 
For the remaining materials (coke, pumice, coal char ex situ) relatively much smaller values of the coefficient of anisotropy prove the strong influence of the flow direction on their permeability but, at the same time, it does not affect the intensity of gas permeability - the coefficients of anisotropy have similar values throughout the entire range of the measurement.

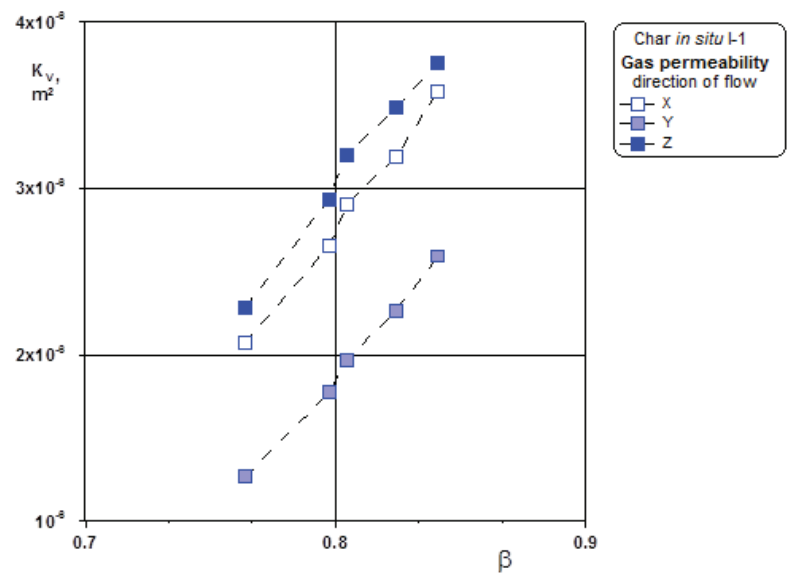

Fig. 7. Gas permeability of coal char in situ as function of material anisotropy.

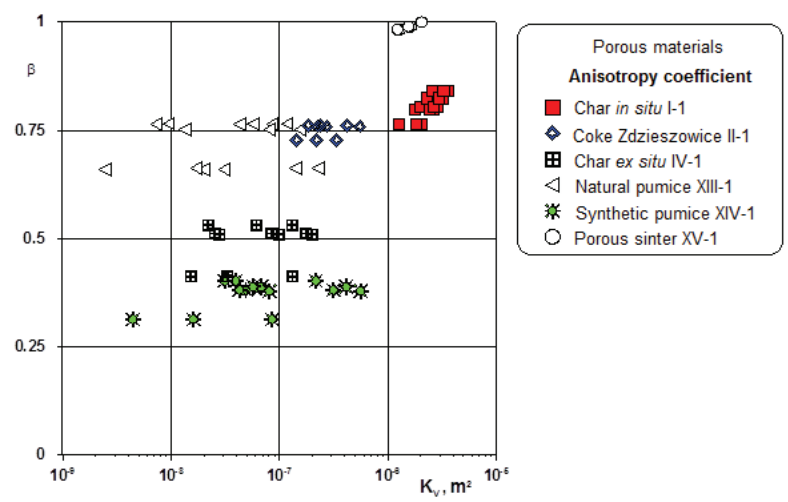

Fig. 8. Coefficient of anisotropy referred to the entire permeability of porous materials.

This may prove the repeatable structure of this group of materials but their hydrodynamic characteristics are closely related to this structure.

On the other hand, the measurement results shown in Fig. 9 (average values) prove a falling tendency for changes to the coefficient of anisotropy with respect to the effective porosity (7):

$$
\varepsilon_{e f}=(0.5 \div 0.8) \varepsilon_{b}
$$

where: $\varepsilon_{\mathrm{ef}}$ - effective porosity; $\varepsilon_{\mathrm{b}}$ - absolute porosity.

Three structural groups of materials may be classified: The first (independent) group consists of porous agglomerate (polyamide) with an effective porosity of around $25 \%$ and a high coefficient of anisotropy, undoubtedly due to the homogeneous structure of this material with the constant dimension and curvature of micro-channels in the whole volume.

Another group contains materials resulting from the thermal carbon processing - coal chars and coke. Their effective porosity is around $30-40 \%$ and the coefficient of anisotropy ranges from 0.5 to 0.8 .

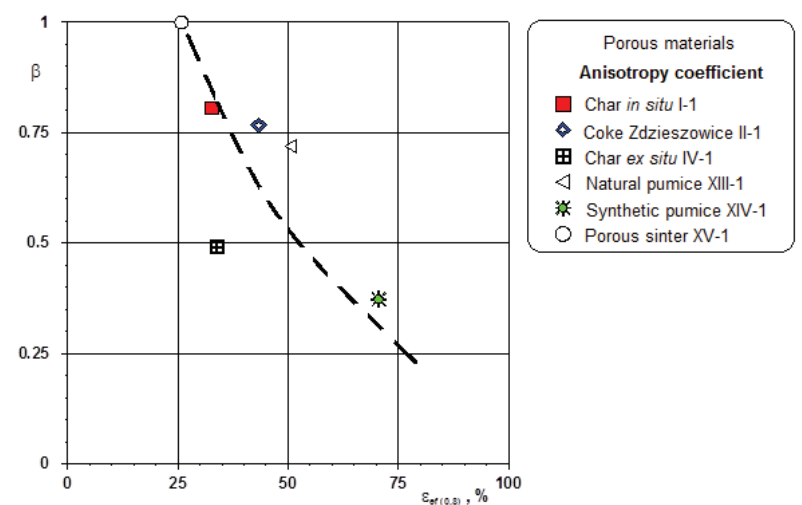

Fig. 9. Coefficient of anisotropy referred to effective porosity.

Coal char in situ has the much more gap-shaped structure whose dimensions of micro-channels are much greater compared to coal char ex situ which has a lot of small and meandering micro-channels with variable diameters, that are sometimes connected with microgaps. On the other hand, coke whose structure is considerably different is moderately anisotropic (at the level of coal char). This is, undoubtedly, affected by the meandering structure of coke channels with a greater dimension of pores compared to coal chars but, at the same time, those pores are frequently blind and closed for the flow. The third group is pumices with the effective porosity of $50-70 \%$. Their structural features considerable differ from one another but the anisotropy of natural pumice is moderate (at the level of coke), whereas synthetic pumice has the smallest level of anisotropy. Undoubtedly, this is caused by the directional structure of this material obtained in the process of blowing pumice foam.

Similar conclusions are drawn by analysing the level of anisotropy of porous materials with respect to the socalled coefficient of effective permeability[15]. It is described by dependency (8):

$$
K_{e f}=\sqrt{K_{h} K_{v}}
$$

where: $\mathrm{K}_{\mathrm{ef}}$ - coefficient of effective permeability, $\mathrm{m}^{2} ; \mathrm{K}_{\mathrm{h}}$ - coefficient of horizontal permeability, $\mathrm{m}^{2} ; \mathrm{K}_{\mathrm{v}}$ coefficient of vertical permeability, $\mathrm{m}^{2}$;

this coefficient characterises average conditions resulting from gas permeability in the horizontal and vertical flow configuration.

The results for the same materials as for the previous once sorted on the basis of this coefficient of anisotropy are shown in Fig. 10. Those results prove that the materials with the excessive fissuring such as coal chars in situ have a considerably anisotropic structure and a very good permeability. On the one hand, it proves that this group of coal chars is characterised by considerable fissuring but, on the other hand, is has a relatively large free area for the gas flow in comparison with the porous polyamide. On the other hand, the materials such as coke, natural pumice and coal char ex situ belonging to the group of materials with moderate anisotropy have relatively limited permeability. The very opposing 
anisotropy is characteristic for synthetic pumice whose structure restricts gas flow conditions with the aforesaid consequences.

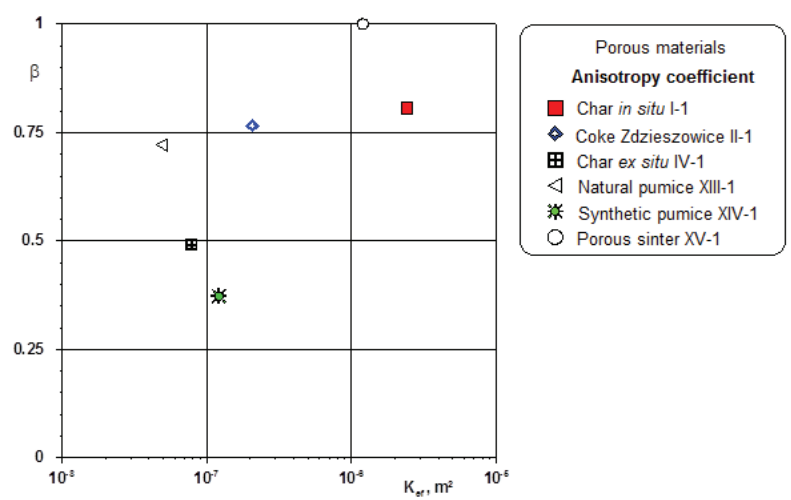

Fig. 10. Coefficient of anisotropy of porous materials - average values.

The distribution of experimental points show in Fig. 9 and Fig. 10 proves that the scale of anisotropy of the porous materials may be very large, which depends on the material structure and its effective porosity.

\section{Conclusions}

The conducted experimental research results in the following conclusions.

It has been proven that conditions of the quantitative assessment of hydrodynamics are affected by such characteristic parameters of the porous deposit as anisotropic properties of its structure. It considerably affects the gas permeability of the tested materials, which is considered in the theoretical assessment of this hydrodynamics;

The experimental evaluation of flow factors resulting from effective permeability of the porous deposit makes it possible to materialise the gas flow conditions, which is essential for the practical use of the measurement results.

The results of our own research quite well correlate those features in different process aspects resulting from the source models.

The research results on hydrodynamics of gas flow through frame-based porous deposits, and the proved usefulness of the process assessment of that research may, in many cases, be practically used to immobilise of methanogenic microorganisms in adhesive deposits

The work done in the framework of a project funded by the National Research and Development Centre implemented the program BIOSTRATEG, contract No. BIOSTRATEG2/ 298357/8 / NCBR / 2016 dated 05.18.2016 r Warsaw

\section{References}

1. Z. Wiłun Z, Zarys geotechniki [Geotechnical outline], (WKiŁ, Warszawa, 1987)

2. G. Wałowski, Hydrodynamika przepływu gazu przez złoże porowate: praca doktorska [Hydrodynamics of gas flow through porous deposits: doctoral thesis], Politechnika Opolska, Opole (2015)

3. J. Demichowacz-Pigoniowa, Obliczenia fizykochemiczne, Termodynamika chemiczna $i$ nauka o fazach, [Physicochemical calculations, Chemical thermodynamics and phases learning], Wrocław (1975)

4. T. Strzelecki, S. Kostecki, S. Żak, Modelowanie przeptywów przez ośrodki porowate [Modeling flows through porous media], (Dolnośląskie Wydawnictwo Edukacyjne, Wrocław, 2008)

5. G.A. Aksielrud, M.A. Altszuler, Ruch masy $w$ cialach porowatych [Movement of mass in porous bodies] (WNT, Warszawa, 1987)

6. A. P. Mozhaev, J. Eng. Phys. Thermophys. 75, 2, 371-383 (2002)

7. J. Hapanowicz, Przepływ ciekłych układów dyspersyjnych. Studia i monografie, z. 204 [Flow of liquid dispersion systems. (Studies and monographs, no. 204, Politechnika Opolska, Opole, 2007)

8. K. Liszka, Podstawy eksploatacji złóż ropy. Skrypty uczelniane 869 , [Basics of exploitation of oil fields. (University scripts 869, AGH, Kraków, 1982)

9. G. Wałowski, G. Filipczak, Inżynieria i Aparatura Chemiczna, 51, 6, pp. 396-397 (2012)

10. G. Wałowski, G. Filipczak, J. Sustainable Min. (2016) http://dx.doi.org/10.1016/j.jsm.2017.03.003

11. G. Wałowski, G. Filipczak, E. Krause, Hydrodynamika przepływu gazu w porowatych strukturach karbonizatu $w$ aspekcie technologii podziemnego zgazowania węgla. Młodzi dla Techniki 2013. Young for Technic 2013, Politechnika Warszawska, Płock, pp. 253 (2013)

12. J. Lu, D. Tiab, F.H. Escobar, J. Eng. Appl. Sci. 8, 6, pp. 425-434, (2013)

13. E.E. Oaikena, J. Oloro, Greener J. Phys. Sci. 3, 3, pp. 97-109, (2013)

14. A. Olufemi Bamidele, A.F. Olugbenga, O. Olusegun, Petroleum \& Coal 51 2, pp. 91-99, (2009)

15. A. Okwananke, S.O. Isehunwa, Mat. Conference: Analysis of water cresting in horizontal wells. Society of Petroleum Engineers Inc., 32nd Annual SPE International Technical Conference and Exhibition in Abuja, SPE 119733, pp. 1-10, Nigeria, August 4-6 (2008) 